\section{Japan keeps its options open on genome sequencing project}

Tokyo

JAPAN's role in world-wide efforts to sequence the human genome remains undecided in a new report to the Science and Technology Agency. Perhaps for political reasons, given that the powerful Ministry of Finance has yet to back the project, all possibilities are left open.

The 40-page report, compiled by the Council for Aeronautics, Electronics and Other Advanced Technologies, covers all aspects of human genome analysis, including chromosome sorting, gene mapping and sequencing, automation of analytical procedures, cell banks, data processing and storage, and international collaboration. But, apart from stressing the need for automated analytical techniques and the importance of human genome analysis for diagnosis and treatment of genetic disease, the report gives absolutely no indication of the future course Japan is likely to take.

For example, no indication is given of whether mapping or sequencing of genes should be stressed, although this is a major point of contention among proponents of the human genome project in the West. And the report says it is very important to consider the possibility of setting up one large-scale facility to carry out the analysis. But it then calls for careful examination of whether one or several small facilities should be established. Some academics on the council's biotechnology subcommittee and working group on human genome analysis favour one large facility, whereas some agency officials favour several small facilities.

Surprisingly no mention is made of the technology for automated DNA sequencing that has already been developed in Japan. Professor Akiyoshi Wada of Tokyo University, a member of the sub-

\section{Institute of Molecular Pathology, Vienna}

IN our issue of 9 June 1988 (333, 490; 1988), we published an article on the opening of the Institute of Molecular Pathology in Vienna. It has been suggested to us that the juxtaposition of the article and the accompanying cartoon might be read by some as conveying the impression that the institute was concealing from the public the true nature of its activities.

We wish to make it clear that no such impression was intended and we apologize for such distress as may have been caused to the director, Professor Max Birnstiel, and to the staff of the Institute of Molecular Pathology.

committee and working group, in collaboration with industry and with the backing of the agency has been developing various machines for several years.

Seiko has developed robot systems for base-specific fragmentation of DNA based on the Sanger method; Tosoh (formerly Toya Soda) is developing instruments to pick up specific fragments of chromosomes; Fuji Photo Film Co. has produced a system for mass production of films for gel electrophoresis and autoradiography; Hitachi Software and Seiko have independently developed automatic scanners to read autoradiograph films; Hitachi has a laser system for real-time analysis of DNA sequences on gels marked by fluorescence; and Mitsui Knowledge Industry Co. has software for matching up DNA sequences.

Eiichi Soeda at the Institute of Physical and Chemical Research and colleagues at the institute's life science centre in Tsukuba are trying to combine these machines into one automatic system. And a small committee has been established in the institute, including Wada, to map out

\section{Paris}

Serge Feneuille, director-general of the largest French science research organization, CNRS, unexpectedly resigned on 23 June. Although Feneuille's departure coincides with a recent change in government and the appointment of a new Minister for Research, he has denied that there is any connection. But, as a friend of the dislodged conservative government, Feneuille's chances of carrying out the radical reforms he was appointed to oversee have been definitively stymied by the socialists' pro-research policy (see Nature $333,584 ; 1988)$. Now the tune has changed, he may have felt he was no longer the man for the job.

Feneuille, who comes from industry, was appointed in 1986 by Alain Devaquet, Minister for Research in the then newly elected right-wing government. The CNRS, which conservative critics have long felt is too hierarchical and dominated by left-wing union influence, had already been targeted for reforms before the socialists' last period in office, from 1981 to 1986. But when Devaquet tried to make changes in the CNRS, by dissolving an appointments committee and blocking new recruitments, he started a legal imbroglio which upset the organization for over a year (see Nature 327, 647; 1987).

Soon after Feneuille took up his post in June 1986, it became clear that he would

\title{
Head of CNRS returns to industry
}

the best route to follow. Wada says that the laser fluorescent method will probably be favoured over autoradiography. At present about 95 per cent of DNA sequencing is carried out by autoradiography, he says, but the trend in Europe and the United States is towards techniques based on fluorescence. The committee has a short-term goal of reading 100,000 bases per day. And Wada is confident this target can be reached in "a year or two". But Wada's ultimate aim is a system that can handle one million bases per day. Much will depend on how much money the Japanese government is prepared to put into the project; for this fiscal year only $¥ 207$ million (about \$1.5 million) has been allocated to the Science and Technology Agency's project, a fraction of the amount being spent in the United States.

The council report makes a vague call for international cooperation. The Science and Technology Agency opened a window of communication with the US Department of Energy last year. But Wada does not expect this window to be used until responsibility for handling the human genome project in the United States has been sorted out among the various US agencies involved.

David Swinbanks

have to wait until the storm died down before reforms could be made. In the meantime, Jacques Valade replaced Devaquet at the ministry and, when the CNRS had almost returned to normal 18 months later, the government changed again.

In the past ten years, the CNRS, with its 25,600 staff and FF8,900 million ( $\$ 850$ million) budget, has had five changes of director. Successive ministers and directors have seen the need for changes but this political hot potato has always been handled gingerly. Ironically, the CNRS annual report was published on the day of Feneuille's resignation. In his preface, written before the recent elections, he makes no secret of the year's turmoil, but says that efforts to "modernize" the organization had been started, without which the CNRS would continue to suffer "burdens of all kinds, running the risk of paralysis beneath often excessive regulations and outdated practices".

Feneuille is now returning to industry, but has promised to continue in office until a successor is found. Although the new research minister, Hubert Curien, shares with his predecessors a desire to open the state research organizations to industry, many feel that the new director will be an academic, like himself. The issue of reforms, which few deny are necessary, will once again be inherited and, perhaps, once again deferred.
Peter Coles 